\title{
Examination of Alternative Catalysts for Biomass Direct Liquefaction
}
A. D. Tran
D. Z. Rogers
SRI International
Menlo Park, California

August 1985

Prepared by SRI International for Pacific Northwest Laboratory under Contract DE-AC06-76RLO 1830 with the U.S. Department of Energy

Pacific Northwest Laboratory Operated for the U.S. Department of Energy by Battelle Memorial Institute 


\title{
DISCLAIMER
}

This report was prepared as an account of work sponsored by an agency of the United States Government. Neither the United States Government nor any agency thereof, nor any of their employees, makes any warranty, express or implied, or assumes any legal liability or responsibility for the accuracy, completeness, or usefulness of any information, apparatus, product, or process disclosed, or represents that its use would not infringe privately owned rights. Reference herein to any specific commercial product, process, or service by trade name, trademark, manufacturer, or otherwise, does not necessarily constitute or imply its endorsement, recommendation, or favoring by the United States Government or any agency thereof. The views and opinions of authors expressed herein do not necessarily state or reflect those of the United States Government or any agency thereof.

\author{
PACIFIC NORTHWEST LABORATORY \\ operated by \\ BATTELLE \\ for the \\ UNITED STATES DEPARTMENT OF ENERGY \\ under Contract DE-AC06-76RLO 1830
}

\begin{tabular}{|c|c|}
\hline \multicolumn{2}{|c|}{$\begin{array}{c}\text { Printed in the United States of America } \\
\text { Available from } \\
\text { National Technical Information Service } \\
\text { United States Department of Commerce } \\
5285 \text { Port Royal Road } \\
\text { Springfield, Virginia } 22161\end{array}$} \\
\hline \multicolumn{2}{|c|}{$\begin{array}{l}\text { NTIS Price Codes } \\
\text { Microfiche A01 }\end{array}$} \\
\hline \multicolumn{2}{|c|}{ Printed Copy } \\
\hline Pages & $\begin{array}{l}\text { Price } \\
\text { Codes }\end{array}$ \\
\hline $001-025$ & $\mathrm{~A} 02$ \\
\hline 026-050 & $\mathrm{A03}$ \\
\hline 051-075 & A04 \\
\hline $076-100$ & A05 \\
\hline $101-125$ & $\mathrm{~A} 06$ \\
\hline $126-150$ & A 07 \\
\hline $151-175$ & 108 \\
\hline $176-200$ & 109 \\
\hline $201-225$ & A010 \\
\hline $226-250$ & A 011 \\
\hline $251-275$ & A012 \\
\hline $276-300$ & $\wedge 013$ \\
\hline
\end{tabular}




\author{
A. D. TRAN \\ D. Z. ROGERS \\ SRI International \\ Menlo Park, California
}

August 1985

Prepared by SRI International

for Pacific Northwest Laboratory under Contract DE-AC06-75RLO 1830

with the U.S. Department of Energy Agreement B-96246-A-O?

Pacific Northwest Laboratory

Richland, Washington 99352 


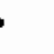




\section{PREFACE}

This report is submitted in partial fulfillment of the contractual obligation for subcontract No. B-96246-A-Q, titled

"Examination of Alternative Catalysts for Biomass Direct

Liquefaction." The report summarizes work performed under this subcontract during the period 16 April 1981 through 30 June 1982. The research program was performed in the Chemistry Laboratory of the Physical Sciences Division under the supervision of Donald L. Ross. The work was performed by An D. Tran under the technical direction of Donald Z, Rogers. 
• 


\section{SUMMARY}

The goal of the work performed under this contract was to determine the ugefulness of vater-soluble transition metal salts as catalysts for the direct liquefaction of woodmeal in a carbon monoxide steam process. The work under this contract was divided into two tasks. Task I was a broad spectrum survey of water-soluble transition metal salts as catalysts for direct liquefaction. Task II was an indepth investigation of salts that showed catalytic activity in Task I.

Fifteen different transition metals vere examined in Task 1 , with several salts containing different ligands being tested in each case. We found that potassium tetracyanonickelate was superior to the other salts tested with respect to the yields of toluene-soluble oils produced. The yields obtained with tetracyanonickelate as catalyst were similar to those obtained with potassium octacyanomolybdate in our earlier work.

Our work in Task II consisted of a more in-depth investigation of the liquefaction of woodmeal with tetracyanonickelate and octacyanomolybdate as catalysts. The role of ph and the reducing gas, and the effect of the ligand on the yields of toluene-soluble products were examined.

The results of these studies have led to the following four conclusions on the mechanism of liquefaction catalysis by watersoluble transition metal salts: 
1. Certain salts of nickel and molybdenum are the most effective for liquefaction in a carbon monoxide/steam process.

2. The metal ligand and the $\mathrm{pH}$ of the starting slurry, as well as the metal ion, are important in determining the yield of toluene-soluble products.

3. The liquefaction of woodmeal by metal salts wen carbon monoxide is the reducing gas is strongly affected by formate chemistry, with significant participation of the metal ion as a hydrogenation cacalyst.

4. The liquefaction of woodmeal by metal salts when hydrogen is the reducing gas is dependent on the action of the metal ion as a hydrogenation catalyst, with little or no participation by formate. 
CONTENTS

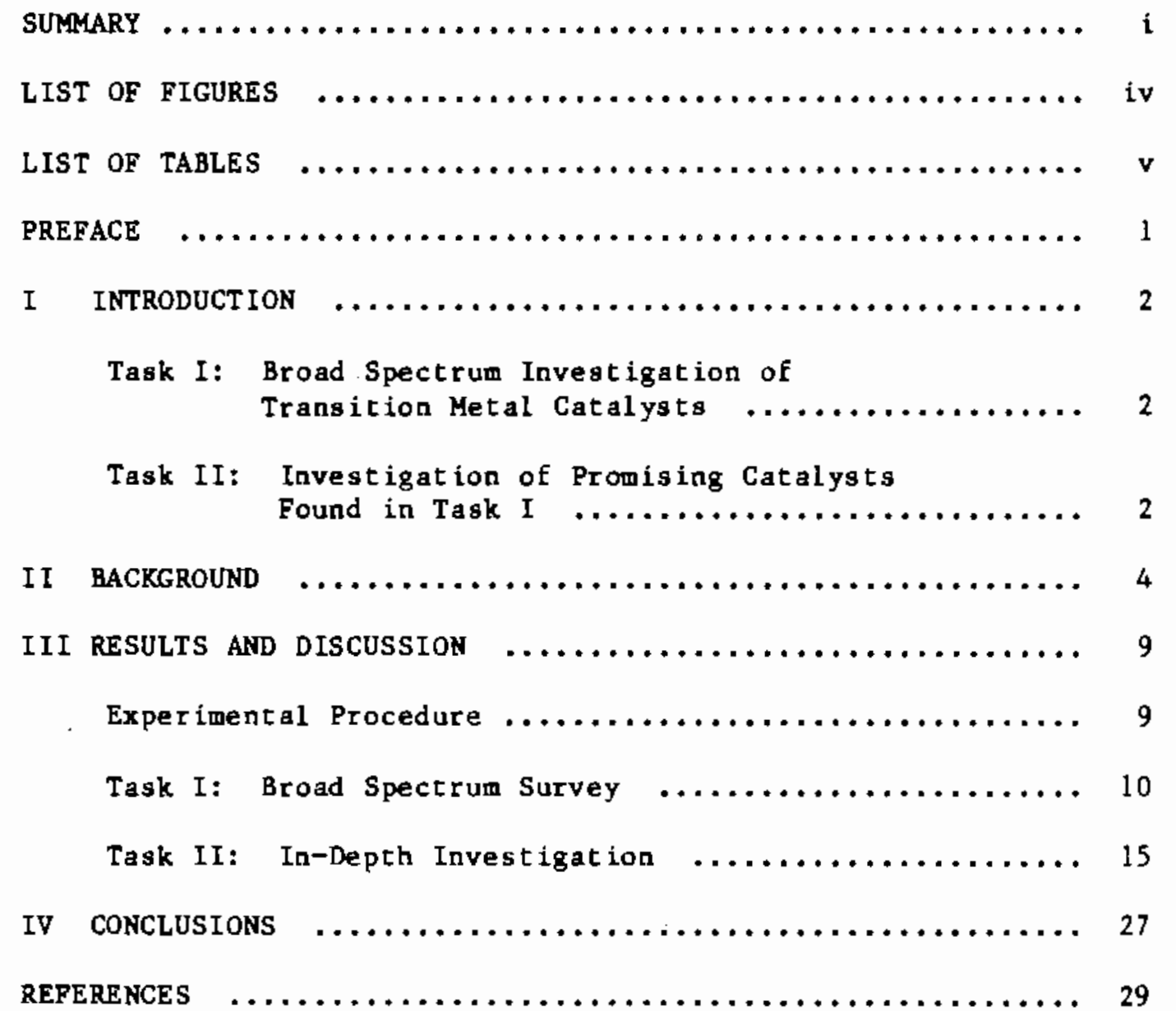




\section{FIGURES}

1 pH Dependence of Woodmeal Liquefaction in a Carbon

Monoxide Atmosphere ............................ 19

$2 \mathrm{pH}$ Dependence of Tetracyanonickelate Catalyzed

Liquefaction in a Carbon Monoxide Atmosphere ......... 20

3 pH Dependence of Woodmeal Liquefaction in a Hydrogen

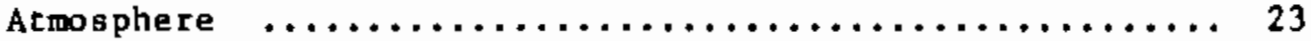

4 Formate-Catalyzed Liquefaction as a Function of

Reducing Gas Composition at 600 psig Initial Pressure ... 24

5 Formate-Catalyzed Liquefaction as a Function of

Reducing Gas Composition at 1000 psig Initial Pressure .. 25 
TABLES

1 Activities of Transition Metal Salts in Direct

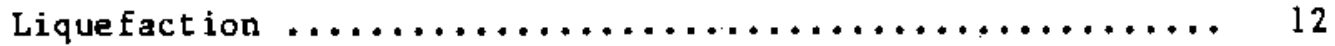

2 Effect of the Ligand on the Catalytic Activity of Iron

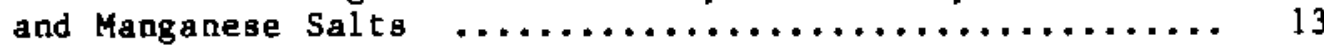

3 Cyanide Salts as Liquefaction Catalysts ............. 16

4 Effect of pH on Toluene-Soluble Product Quality ........ 21 
. 


\section{INTRODUCTION}

The goal of the work described in this summary report was to determine wich water-soluble salts of transition metals have the potential to act as catalysts for direct liquefaction of biomass in a carbon monoxide/steam process. The efforts under this contract vere conducted under the following statement of work.

Task I: Broad Spectrum Survey of Transition Metal Cacalysts Conduct a broad spectrum survey of transition metal salts to determine wich metals have the potential to be effective catalysts for direct biomass liquefaction in a carbon monoxide/steam process. Metals to be tested include titanium, vanadium, chromium, cobalt, iron, copper, zinc, niobium, ruthenium, rhenium, cesium, tungsten, lead, and manganese.

Task II: Inveatigation of Promising Catalysts Found in Task I Further investigations on catalyst candidates found to be effective in Task I, with specific attention to decermining the compounds and oxidation states of the active metals that are most effective as liquefaction catalysts.

Because our results in Task I indicated that the activity of metals as liquefaction catalysts depends critically on the ligand associated with the metal, much of our work was an investigation of the role of the ligand in the liquefaction mechanism. As a part of these 
investigations we determined the effect of starting $\mathrm{pH}$ and reducing

gas identity on the liquefaction reaction. 


\section{I BACKGROUND}

For more than a century, the pyrolysis of wood has been known to produce heavy oils. These oils vere usually. the undesired by-products in the manufacture of charcoal, which is the main product of simple pyrolysis of wood or other biomass in an inert atmosphere. Periodically during the tuentieth century, due to recurrent shortages of petroleum, there has been much interest in the liquefaction of biomass to provide liquid transportation fuels. Before the discovery of the Texas oilfields, degtructive distillation of wood to produce methanol was investigated on a pilot plant scale, in particular by the Ford Motor Company. During World War II, there were extensive efforts to produce ethanol from biomass. Although the wartime interest was mostly negated by the discovery of the Mid-East oilfields, the Arab oil embargo of 1973 precipitated a dramatic revival of interest and effort in research on direct liquefaction of biomass.

It was in this context that a group led by Appell at the Pittsburgh Energy Research Center found that high yields of heavy oils could be obtained from biomass liquefaction with $5 \%$ sodium carbonate as catalyst and carbon monoxide as reducing agent. 1 During the period of 1974 to 1976 a process development unit (PDU) was constructed at Albany, Oregon, to develop the work of Appel1 into a continuous process. Although beset by initial design and technical problems of the original facility design, Rust Engineering has recently succeeded in producing several barrels of purely wood-derived oil in the facility. 2 
A program was developed in support of the PDU facility that included Battelle Pacific Northwest Laboratory (PNL), Lawrence Berkeley Laboratory (LBL), and SRI International (SRI) as contractors. PNL has provided analytical support to the facility, and in addition has also undertaken extensive investigations into process parameters, including catalyst selection and function. LBL initially contracted to provide technical evaluation and monitoring services, and later began an experimental program. LBL has now completed construction of a bench-scsle continuous flow reactor that is being used to provide information on process variables in a continuous flow biomass liquefaction process. 3

The Energy Center of SRI conducted a major study ("Mission Analysis for The Federal Fuels From Biomass Program") on the feasibility and profected market penetration of biomass derived fuels.4 Later SRI began an experimental program to investigate the basic chemistry and mechanisms involved in direct biomass liquefaction. SRI's experimental program comprised two sequential projects. The results of the first profect have been reported; ${ }^{5}$ this report is a summary of the results of the second project. The history of the Department of Energy program of research in direct liquefaction and recent advances in the area of liquefaction technology are given in a recent review by LBL, 6

In the initial stages of work on the first project, we were examining the use of concentrated solutions of base with carbon monoxide for biomass liquefaction. Potassium hydroxide was a very effective base; liquefaction of woodmeal with $\mathrm{KOH} / \mathrm{H}_{2} \mathrm{O} / \mathrm{CO}$ gave a $28 \%$ 
yield of toluene-soluble heavy oils containing $19 \%$ oxygen. We found that if the water layer from this liquefaction was neutralized, it was an equally effective medium for subsequent voodmeal liquefaction, even though it was nearly neutral ( $\mathrm{pH}$ ). Analysis of this water layer showed it to contain eight metal ion species, representing all the elements in the autoclave alloy, presumably leached from the autoclave by the strong alkali.

Although formate was undoubtedly present in the neutralized water, we hypothesized that the metal ions might also be effective catalysts in this neutral liquefaction. Because molybdenum was by far the most abundant metal species ( $1000 \mathrm{ppm})$, we chose an appropriate water-soluble salt, sodium molybdate, to test this hypothesis. We found that liquefaction of woodmeal with sodium molybdate at a molybdenum concentration of $1000 \mathrm{ppm}$ in water at $\mathrm{pH} 5$ under carbon monoxide gave a $36 \%$ yield of toluene-soluble products. We then performed a detailed investigation of the use of various molybdenum salts as liquefaction catalysts, an account of which is given in our previous summary report. 5

Low valent molybdenum salts that were tested showed no activity as catalysts. These included molybdenum hexacarbonyl and other, charged carbonyl complexes. Potassium octayanomolybdate, in which the molybdenum is in a +4 oxidation state, was the most active catalyst found, giving yields of toluene-soluble products as high as $42 \%$. While the molybdate and octacyanomolybdate catalysts could be recycled to some extent, there was a significant loss of activity on recycle. Possible concributions from formate chemistry were neither excluded 
nor demonstrated.

The technical background that is most relevant to our work is that on the liquefaction of biomass using metal catalysts. Catalytic hydrogenation of biomass or biomass components such as lignin, either by classical, heterogeneous hydrogenation catalysts, or by impregnation of the biomass with metal salts, has been of interest for over fifty years. In 1931 the hydrogenation of biomass catalyzed by common transition metal hydroxides, nickel formate, ammonium molybdate, and ammonium chromate vere reported, 7 and in 1931 a second report appeared on the hydrogenation of saudust impregnated with hydroxides of copper, cobalt, and nickel, sulfides of cobalt, nickel, and iron, rolybdic acid, and zinc chloride. 8

Hydrogenation of biomass over metal oxides and sulfides has been investigated extensively. Heinemann has reported the liquefaction of sugar cane residues over molybdenum oxide and molybdenum sulfide, 9 and the hydrotreating of lignin over iron oxide catalysts was investigated in-depth by Japanese workers in collaboration with Crown-Zel lerbach Corp. 10 Other major contributors to the study of metal oxide catalysts include Kashima, 11,12 Hibbert and coworkers, 13-16 and Hachihama. 17-19 Various forms of nickel catalysts 20-22 including Raney nickel23-25 have been reported to be effective catalysts for biomass hydrogenation. Carbonyls of cobalt, nickel, and iron have also been investigated. 26-29

This report describes the results of our investigation of direct I iquefaction of woodmeal in a carbon monoxide/steam process using water-soluble transition metal salts as catalysts. Also we report our 
investigations on the possible role of formate in metal catalyzed liquefactions, and vice-versa. Our work differs from that referenced above in that our process involves simple addition of a vater-soluble salt to a reaction mixture consisting only of biomass, water, and the reducing gas. Thus the catalyst is present as an aqueous solution, and not as a suspended solid. An additional difference is the use of carbon monoxide ingtead of hydrogen as the reducing medium. 


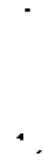

. 
III RESULTS AND DISCUSSION

\section{Experimental Procedure}

The standard autoclave procedure used for all liquefaction ruas was as follows. In all reactions reported here, 5 grams Douglas fir woodmeal, $15 \mathrm{ml}$ water, and $1.5 \mathrm{millimoles}$ of the catalyst were used. The autoclave (a standard 300-ml 316 stainless steel model manufactured by Autoclave Engineers) was charged with the desired biomass, water, and catalyst, and sealed in accordance with the manufacturer's instructions, except that a copper gasket was used in place of the standard stainless steel fitting. (The copper gasket is inert to the non-corrosive environments under investigation, and allows the autoclave to be more easily sealed.) The mixture was stirred slowly while the vessel was pressurized to 1000 psig with nitrogen and checked for leaks.

After the nitrogen was vented, the vessel was purged with 600 psig of the reaction gas, and charged with the desired pressure of the reaction gas. The magnetic stirrer was then set for a rate of 1500 rpm and the external furnace started. Internal temperature of the reaction vessel was continuously recorded and at appropriate times the vessel pressure noted. The standard conditions for all experiments reported, unless otherwise noted, were a reaction temperature of $350^{\circ} \mathrm{C}$ for 45 minutes, with a beginning pressure of 600 psig.

After the vessel had been at the desired reaction temperature for the appropriate time, the external furnace was removed and the reaction vessel cooled with an external fan. In some cases, after the 
final pressure at roon temperature was recorded, a sample of the of $f$ gases was collected and analyzed by gas phase chromatography. The remaining gases were then vented and the autoclave opened. The aqueous fraction of the product was removed by pipet. The aqueous fractions were not analyzed. The nonwater-soluble materials were collected by washing the autoclave surfaces with $200 \mathrm{ml}$ toluene. The resulting mixture was then refluxed $\left(115^{\circ} \mathrm{C}\right)$ for one hour under nitrogen atmosphere with azeotropic removal of water. The amounts of water removed were too small to entrain any significant amounts of organic products. After cooling to roon temperature, the mixture was filtered by vacuum to yield the toluene-insoluble fraction as a brownish-black solid. The toluene was removed from the filtrate in vacuo to give the toluene-soluble product. In several cases the tolvene solvent was examined for low molecular weight products that might have been lost by this procedure; no such light products were found.

In several cases experiments were repeated to determine the reproducibility of the results. In every case yields were reproducible to within $3 z$ of their own value, e.g., a yield of $40 z$ has a possible range of values from $39 \%$ to $41 \%$.

\section{Task I: Broad Spectrum Survey}

We tested water-soluble salts of the fifteen transition metals proposed in Task I for catalytic activity in direct liquefaction in a carbon monoxide/steam process. For each metal examined we tested several different salts containing different ligands. The highest 
yield of toluene-soluble products obtained for each metal are shown in Table 1. (Results with sodium molybdate and sodium carbonate are shown at the bottom of Table 1 for comparison.) In each case the other salts of the metal gave lower yields than the salt shown. Reactions giving lower yields are reported in Table 2. All experiments were run at $350^{\circ} \mathrm{C}$ for 45 minutes unless otherwise ind icated.

of the fifteen metals tested, eight (cobalt, chromium, cesium, iron, manganese, nickel, ruthenium, and rhenium) showed some activity as catalysts, giving yields of toluene-soluble products of $30 \%$ or greater. Because of their high cost, ruthenium and rhenium are not likely to be of practical interest, but they are of scientific interest and were tested for completeness. With the exception of ruthenium oxide and rhenium carbony 1 , al 1 the effective catalysts gave materials with oxygen contents of $11 \%$ to $17 \%$, with molar $\mathrm{H} / \mathrm{C}$ ratios of 1.1 to 1.3 . Of these eight effective catalysts, potassium tetracyanonickelate was the best, giving yields (42\%) of toluene-soluble products comparable to those obtained with potassium oct acyanomo lybdace.

Results in Task I also showed that the ligand on the metal plays an important role in detemining the catalytic effect of transition metal salts. The effect of ligand on the catalytic activity of cobalt, chromium, iron, manganese, and nickel is shown in Table 2. In each case the best yield of toluene-soluble products was obtained when the the ligand was either cyanide or oxygen. The results of Run 8 (Table 2) also indicated that the $\mathrm{pH}$ of the starting slurry was also 
Table 1

ACTIVITIES OF TRANSITION METAL SALTS IN DIRECT LIQUEFACTION

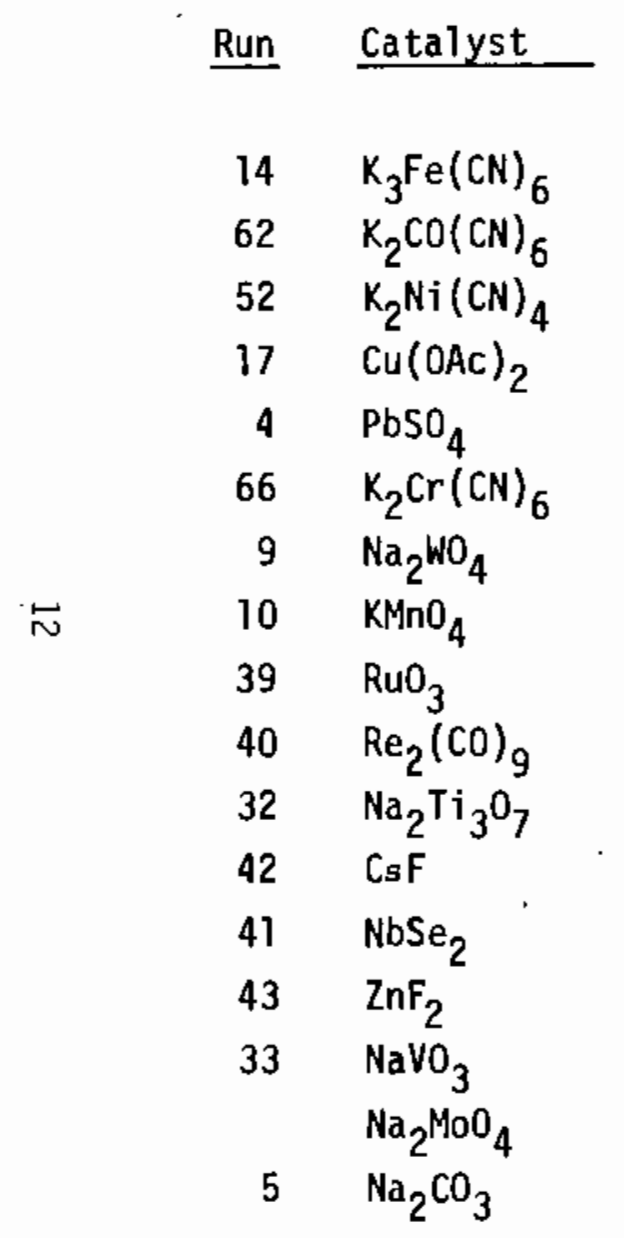

\begin{tabular}{|c|c|c|c|}
\hline Wt䗑 & $\mathrm{Cq}^{\mathrm{b}}$ & $0 \%^{c}$ & $\mathrm{H} / \mathrm{C}^{\mathrm{d}}$ \\
\hline 30 & 48 & 12 & 1.2 \\
\hline 35 & 55 & 13 & 1.2 \\
\hline 42 & 66 & 12 & 1.3 \\
\hline 0 & $m$ & 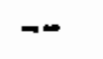 & - \\
\hline 8 & 11 & 24 & 1.2 \\
\hline 35 & 58 & 11 & 1.1 \\
\hline 17 & 25 & 21 & 1.2 \\
\hline 30 & 46 & 17 & 1.1 \\
\hline 45 & 65 & 20 & 1.4 \\
\hline 36 & 47 & 30 & 1.1 \\
\hline 22 & 32 & 23 & 1.2 \\
\hline 35 & 56 & 12 & 1.2 \\
\hline 23 & 32 & 26 & 1.2 \\
\hline 9 & 12 & 23 & 1.1 \\
\hline 26 & 36 & 25 & 1.2 \\
\hline 36 & 56 & 12 & 1.2 \\
\hline 29 & 44 & 19 & 1.1 \\
\hline
\end{tabular}

\begin{tabular}{|c|c|c|c|}
\hline$W t \%^{a}$ & $\mathrm{C} \%$ & $0 \%^{\mathrm{C}}$ & $H / C^{d}$ \\
\hline 12 & 15 & 32 & 1.1 \\
\hline 10 & 70 & 23 & 0.7 \\
\hline 8. & 10 & 29 & 1.1 \\
\hline 46 & 71 & 20 & 0.7 \\
\hline 48 & 66 & 30 & 0.7 \\
\hline 16 & 69 & 23 & 0.8 \\
\hline 23 & 35 & 22 & 0.8 \\
\hline 9 & 12 & 36 & 0.8 \\
\hline 3 & 2. & 54 & 1.0 \\
\hline 9. & 11 & 36 & 0.8 \\
\hline 44 & 55 & 35 & 0.8 \\
\hline 10 & 15 & 78 & 0.9 \\
\hline II & 14 & 32 & 1.0 \\
\hline 38 & 56 & 24 & 0.8 \\
\hline 20 & 36 & 25 & 1.2 \\
\hline 12 & 14 & 39 & 0.7 \\
\hline 15 & 26 & 13 & 0.8 \\
\hline
\end{tabular}

a. Weight of product as a percentage of dry feed.

b. Carbon recovered in product as a percentage of carbon in dry feed.

c. Weight percent by difference.

d. Molar ratio. 
Table 2

EFFECT OF LIGANO ON THE CATALYIIC ACTIYITY

OF TRANSITION METALS

Run Catalyst

$14 \quad \mathrm{~K}_{3} \mathrm{Fe}(\mathrm{CN})_{6}$

19

25

52

28

16

29

20

62

15

26

27

66

7

$$
8
$$

10

18

21

22

\begin{tabular}{|c|c|c|}
\hline$W t^{q^{\mathrm{a}}}$ & $\mathrm{Cs}^{\mathrm{b}}$ & $0 \%^{\mathrm{c}}$ \\
\hline
\end{tabular}

30

15

1

42

13

9

3

35

8

8

2

0
35

35

22

29 (and then $\mathrm{KOH}$ to $\mathrm{PH} 6.5$ )

$\begin{array}{lr}\mathrm{MnO}_{4} & 30 \\ \left.\mathrm{Mn}_{4} \mathrm{OAC}\right)_{2} & 9 \\ \mathrm{MnCl}_{2} & 2 \\ \mathrm{MnSO}_{4} & 2\end{array}$

$\begin{array}{rrr}48 & 12 & 1.2 \\ 23 & 19 & 1.2 \\ 1 & 23 & 1.2 \\ 66 & 12 & 1.3 \\ 15 & 23 & 1.2\end{array}$

$55 \quad 13$

1.2

$12 \quad .22 \quad 1.2$

$\begin{array}{lll}3 & 18 & 1.2\end{array}$

$\begin{array}{lll}-- & -- & --\end{array}$

$\begin{array}{lll}58 & 11 & 1.1\end{array}$

Toluene-insoluble Solids

$\begin{array}{llll}14 & 19 & 1.1 & 30\end{array}$

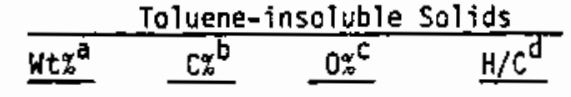

$\begin{array}{llll}12 & 12 & 15 & 1.1\end{array}$

$\begin{array}{llll}26 & 40 & 20 & 0.9\end{array}$

42

63

10

$23 \cdot 0.7$

8

32

30

$\begin{array}{llll}-- & -. & 47\end{array}$

4. $19 \cdot 1.2 \quad 36$

10

33

46

52

$29 \quad 1.1$

44

52

$\begin{array}{lll}48 & 17 & 0.8\end{array}$

$\begin{array}{lll}69 & 25 & 0.7\end{array}$

$\begin{array}{lll}54 & 22 & 0.7\end{array}$

$\begin{array}{lll}70 & 23 & 0.7\end{array}$

$\begin{array}{lll}50 & 21 & 0.8\end{array}$

$\begin{array}{lll}71 & 19 & 0.8 \\ 7 & 0.8\end{array}$

$\begin{array}{lll}71 & 19 & 0.8 \\ 66 & 22 & 0.7\end{array}$

$\begin{array}{lllll}1.1 & 16 & 69 & 23 & 0.8\end{array}$

$\begin{array}{lllllll}33 & 20 & 1.2 & 27 & 41 & 22 & 0.8\end{array}$

$\begin{array}{lllllll}42 & 21 & 1.1 & 11 & 15 & 29 & 0.8\end{array}$

$\begin{array}{rrrrrrr}46 & 17 & 1.1 & 9 & 12 & 36 & 0.8 \\ 13 & 21 & 1.1 & 32 & 49 & 20 & 0.8 \\ 20 & 19 & 1.2 & 40 & 62 & 20 & 0.7 \\ 2 & 20 & 1.2 & 42 & 66 & 19 & 0.8\end{array}$

\footnotetext{
a: Weight of product as a percentage of dry feed.

b. Carbon recovered in product as a percentage of carbon in dry feed.

c. Weight percent by difference.

d. Moiar ratio.
} 
important in determining the result of the liquefaction. (Additional data on the effect of $\mathrm{pH}$ is shown in Table 4.)

We also tested several of the catalysts at temperatures lower than $350^{\circ} \mathrm{C}$. However, potassium permanganate, potassium dichromate, and potasaium ferricyanide were all totally ineffective as catalysts for liquefaction at $250^{\circ} \mathrm{C}$ or $300^{\circ} \mathrm{C}$. This caused us to reexamine our previous results with potassium octacyanomolybdate at temperatures below $350^{\circ} \mathrm{C}$. All our attempts to reproduce these results were unsuccessful. Our earlier, erroneous results with the octacyanomolybdate catalyst at $250^{\circ} \mathrm{C}$ appear to have been due to poor accuracy of the temperature control apparatus. This deficiency was corrected before the current work began by aquisition of an Autoclave Engineers temperature controller specifically designed for use with the autoclave system. It now appears that a temperature of $350^{\circ} \mathrm{C}$ is required for efficient liquefaction no mater what catalyst is used.

At this point in our work we had completed the survey of the transition metal salts. We then turned our attention to a more in depth investigation of the two most promising catalysts, potassium tetracyanonickelate and potassium octacyanomolybdate. Because we had determined that the cyanide complexes of these metals were the most effective catalysts, we investigated in Task II the role of the cyanide ligand, the role of $\mathrm{pH}$, and the relative importance of the metal ion versus the ligand in catalyzing biomass liquefaction. 
Task II: In-Depth Investigation

The seemingly unique activity of cyanide and oxyanion complexes of molybdenum, nickel, and iron made us suspicious that at least part of their catalytic activity could be attributed to in situ formation of formate, which could act as a hydride donor for the hydrogenation of the biomass in the usual fashion. Cyanide could be hydrolyzed directly to formate, while the oxyanion complexes might be basic enough under the reacion conditions to form formate by reaction with carbon monoxide.

To test this hypothesis we made blank runs $\left(350^{\circ} \mathrm{C}\right.$, no biomass) with potassium formate, potassium tetracyanonickelate, potassium ferricyanide, and potassium permanganate under our standard conditions. In each case, evaporation of the water from the reaction product gave potassium formate as the major product in about $85 \%$ yield. These results strongly supported the suspicion that formate was involved in the catalytic liquefaction of woodmeal by the transition metal catalysts.

If the catalytic activity of metal cyanide complexes were due solely to cyanide itself, then all cyanide complexes should give about the same results, regardless of the identity of the metal, and formate itself should be an equally effective catalyst. For this reason we performed a liquefaction run under standard conditions with potassium cyanide as catalyst. A comparison of the result with those of metal cyanide complex catalyzed runs is show in Table 3 . All runs in Table 3 except Run 34 were conducted with 1.5 millimoles of catalyst. 
Table 3

CYANIDE SALTS AS LIQUEFACTION CATALYSTS

\begin{tabular}{|c|c|c|c|c|c|c|c|c|c|}
\hline \multirow{2}{*}{ Run } & \multirow[t]{2}{*}{ Catalyst } & \multicolumn{4}{|c|}{ Toluene-Soluble 0ils } & \multicolumn{4}{|c|}{ Toluene-Insoluble Solids } \\
\hline & & $\underline{\mathrm{Wt} \%^{\mathrm{a}}}$ & $\mathrm{C}^{\mathrm{b}}$ & $0 \%^{\mathrm{c}}$ & $\mathrm{H} / \mathrm{C}^{\mathrm{d}}$ & $\mathrm{Wt}^{\mathrm{a}}$ & $\mathrm{Co}^{\mathrm{b}}$ & $0 \%^{\mathrm{C}}$ & $\mathrm{H} / \mathrm{C}^{\mathrm{d}}$ \\
\hline & $\mathrm{K}_{4} \mathrm{Mo}(\mathrm{CN})_{8}$ & 42 & 66 & 9.6 & 1.3 & 5.0 & 5.0 & 48 & 1.1 \\
\hline 52 & $\mathrm{~K}_{2} \mathrm{Ni}(\mathrm{CN})_{4}$ & 42 & 66 & 12 & 1.3 & 8.0 & 10 & 29 & 1.1 \\
\hline 62 & $\mathrm{~K}_{2} \mathrm{Co}(\mathrm{CN})_{6}$ & 35 & 55 & 13 & 1.2 & 10 & 70 & 23 & 0.7 \\
\hline 66 & $\mathrm{~K}_{2} \mathrm{Cr}(\mathrm{CN})_{6}$ & 35 & 58 & 11 & 1.1 & 16 & 69 & 23 & 0.8 \\
\hline 14 & $\mathrm{~K}_{3} \mathrm{Fe}(\mathrm{CN})_{6}$ & 30 & 48 & 12 & 1.2 & 12 & 12 & 15 & 1.1 \\
\hline 34 & $\mathrm{KCN}(5 \mathrm{mmol})$ & 34 & 53 & 13 & 1.3 & 6 & 8 & 22 & 1.2 \\
\hline
\end{tabular}

a. Weight of product as a percentage of dry feed.

b. Carbon recovered in product as a percentage of carbon in dry feed.

c. Weight percent by difference.

d. Molar ratio. 
The yield of toluene-soluble products obtained with potassium cyanide was very similar to those obtained with cobalt, chronium, and iron cyanide complexes as catalysts. However, runs with tetracyanonickelate and octacyanomolybdate as catalysts gave clearly higher yields than potassium cyanide. Because various forms of nickel and molybdenum are well known for the their ability to act as hydrogenation catalysts, it seemed likely that in these two cases the metal was in fact contributing to the liquefaction reaction. We therefore turned our attention to a more detailed study of these two metals as catalysto for biomass liquefaction.

To help separate the effect of the derived formate and the metal ion, we performed a series of experiments in wich the reducing gas was varied from carbon monoxide to wixtures of hydrogen and carbon monoxide and finally to pure hydrogen. The catalysts selected for these runs were potassium formate, potassium tetracyanonickelate, and potassium octacyanomolybdate. Because the catalytic regeneration of formate requires the reaction of hydroxide with carbon monoxide, we expected that in a hydrogen atmosphere formate would not be an effective liquefaction catalyst. Metal ions, however, would be expected to be effective catalysts in hydrogen, because they can act both as water gas shift catalysts to produce carbon monoxide and as direct hydrogenation catalysts. Therefore, comparing the yields obtained with metal complexes in carbon monoxide and those obtained with metal complexes in hydrogen should provide an indication of the relative contributions of catalysis by formate and catalysis by the metal ion in biomass liquefaction. 
We also suspected from our previous work that the yield of toluene-soluble products in these reactions would depend strongly on the initial pH of the woodmeal slurry. Therefore ve determined a "pH profile" (a plot of yield of toluene-soluble products versus initial $\mathrm{pH}$ ) for these reactions in carbon monoxide and hydrogen atmospheres. Although the initial $\mathrm{pH}$ of the slurry is not equivalent to the actual hydrogen ion activity at the reaction temperature, the initial $\mathrm{pH}$ should serve as a relative measure of these reactivities. For potassium formate and potassium octacyanomolybdate the $\mathrm{pH}$ range examined was from 1 to 12 ; because tetracyanonickelate decomposes in strong acids, the range for nickel was restricted to 3 to 12 .

The $\mathrm{pH}$ profiles for liquefaction in carbon monoxide using potassium octacyanomolybdate and potassium formate are shown in Figure 1. Both catalysts were fully effective at a $\mathrm{pH}$ as low as 6 , and inactive at $\mathrm{pH}$ of 2 or less. Although the formate and the octacyanomolybdate gave profiles with the same shape, significantly higher yields were obtained with the molybdenum salt. The inflection point in both profiles occurs at about the pKa of formate $\left(\mathrm{pK}_{\mathrm{a}}=3.5\right)$. While it is tempting to attribute the the inflection in the $\mathrm{pH}$ profiles to a formate to formic acid transition, there is not sufficient evidence to prove the point. The $\mathrm{pH}$ dependence of the potassium tetracyanonickelate showed a similar dependence (Figure 2). Elemental analyses were performed on selected products from these pH dependence studies (Table 4). For all three catalysts the character of the toluene-soluble products was fairly constant over the $\mathrm{pH}$ range with respect to oxygen content and molar $\mathrm{H} / \mathrm{C}$ ratio. 


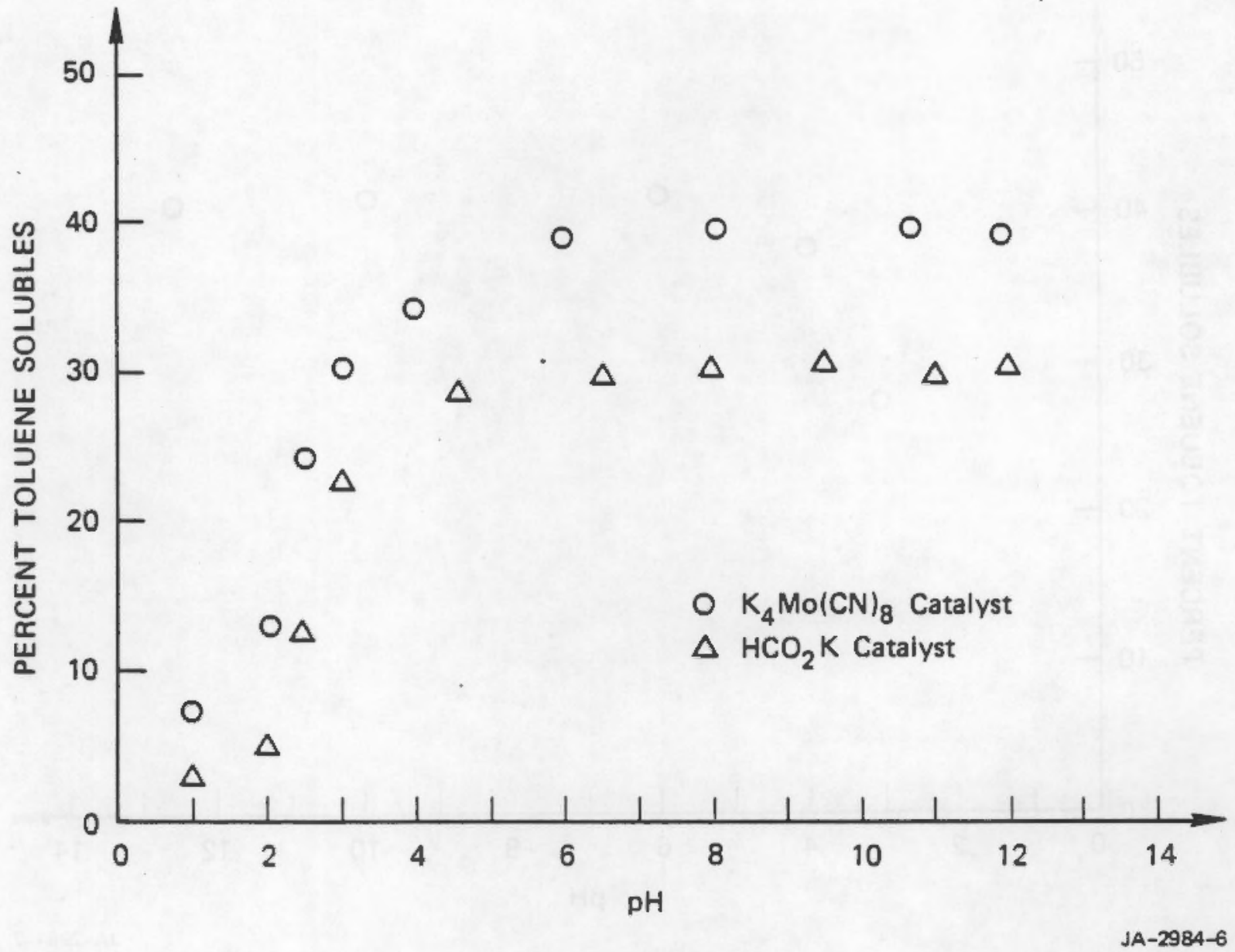

FIGURE 1 PH DEPENDENCE OF WOODMEAL LIQUEFACTION IN A CARBON MONOXIDE ATMOSPHERE 


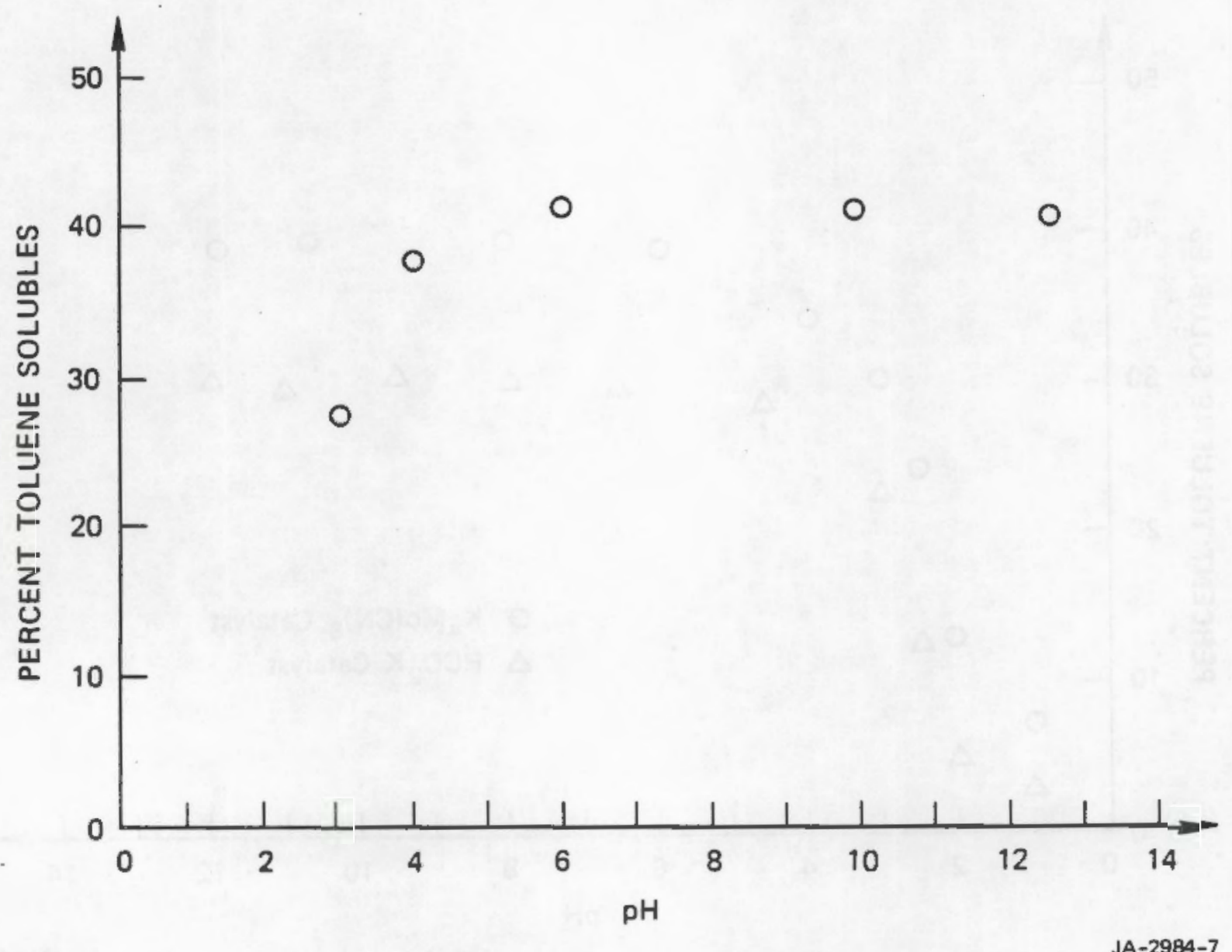

FIGURE 2 PH DEPENDENCE OF TETRACYANONICKELATE CATALYZED LIQUEFACTION IN A CARBON MONOXIOE ATMOSPHERE 
Table 4

EFFECT OF PH ON TOLUENE-SOLUBLE PRODUCT QUALITY

\begin{tabular}{|c|c|c|c|c|c|c|}
\hline \multirow[t]{2}{*}{ Run } & \multirow[t]{2}{*}{ Catalyst } & \multicolumn{4}{|c|}{ Toluene-Soluble 0il } & Toluene-Insoluble Solid \\
\hline & & $W t q^{a}$ & $\mathrm{Cq}^{\mathrm{b}}$ & $0 \%^{c}$ & $H / c^{d}$ & $W t \%^{a}$ \\
\hline & $\mathrm{HCO}_{2} \mathrm{~K}$ & & & & & \\
\hline 75 & $\mathrm{pH}=2$ & 5 & 8.3 & 8.0 & 1.3 & 24 \\
\hline 77 & $\mathrm{pH}=3$ & 23 & 37 & 8.0 & 1.3 & 16 \\
\hline 80 & $\mathrm{pH}=8$ & 30 & 50 & 8.0 & 1.3 & 15 \\
\hline & $\mathrm{K}_{4} \mathrm{Mo}(\mathrm{CN})_{8}$ & & & & & \\
\hline 55 & $\mathrm{pH}=2$ & 13 & 21 & 10 & 1.2 & 19 \\
\hline 64 & $\mathrm{pH}=3$ & 30 & $4 B$ & 11 & 1.3 & 14 \\
\hline 67 & $\mathrm{pH}=8$ & 40 & 69 & 10 & 1.3 & 14 \\
\hline & $\mathrm{K}_{2} \mathrm{Ni}(\mathrm{CN})_{4}$ & & & & & \\
\hline 69 & $\mathrm{pH}=3$ & 28 & 45 & 8 & 1.3 & 14 \\
\hline 52 & $\mathrm{pH}=8$ & 42 & 69 & 12 & 1.2 & 8.0 \\
\hline
\end{tabular}

a. Weight of product as a percentage of dry feed.

b. Carbon recovered in product as a percentage of carbon in dry feed,

c. Weight percent by difference.

d. Molar ratio. 
We also determined the $\mathrm{pH}$ dependence of octacyanomolybdate and formate catalyzed liquefactions in a hydrogen atmosphere; these results are shown in Figure 3. Very different results were obtained in this series of experiments than with carbon monoxide. The octacyanomolybdate showed the same pH profile observed in carbon monoxide, although the yield at full activity was somewhat lower in hydrogen (32\%). However, for the formate catalyst under hydrogen atmosphere all runs between $\mathrm{pH} 2$ and 10 showed little or no catalyst activity (about $10 \%$ yield). Little or no carbon monoxide was produced in the formate runs, while in the octacyanomolybdate runs considerable amounts of carbon monoxide were formed (probably via water-gas shift reactions).

Our results demonstrated that in carbon monoxide formate chemistry is important and perhaps predominant in the liquefaction process. Because carbonate-catalyzed liquefaction is al so thought to depend on formate chemistry, we thought it important for other researchers' work, as well as our own, to determine the activity of formate in various mixtures of carbon monoxide and hydrogen, with the goal of determining what compositions of synthesis gas would give full activity with formate catalysts. Because synthesis gas is much cheaper than carbon monoxide, any practical liquefaction process must use synthesis gas. These results are shown in Figures 4 and 5 .

Figure 4 shows the yields of toluene-soluble products from formate-catalyzed liquefaction as a function of initial reducing gas composition at a starting pressure of 600 psig. A starting carbon monoxide concentration of $70 \%$ is required for full activity. Figure 5 


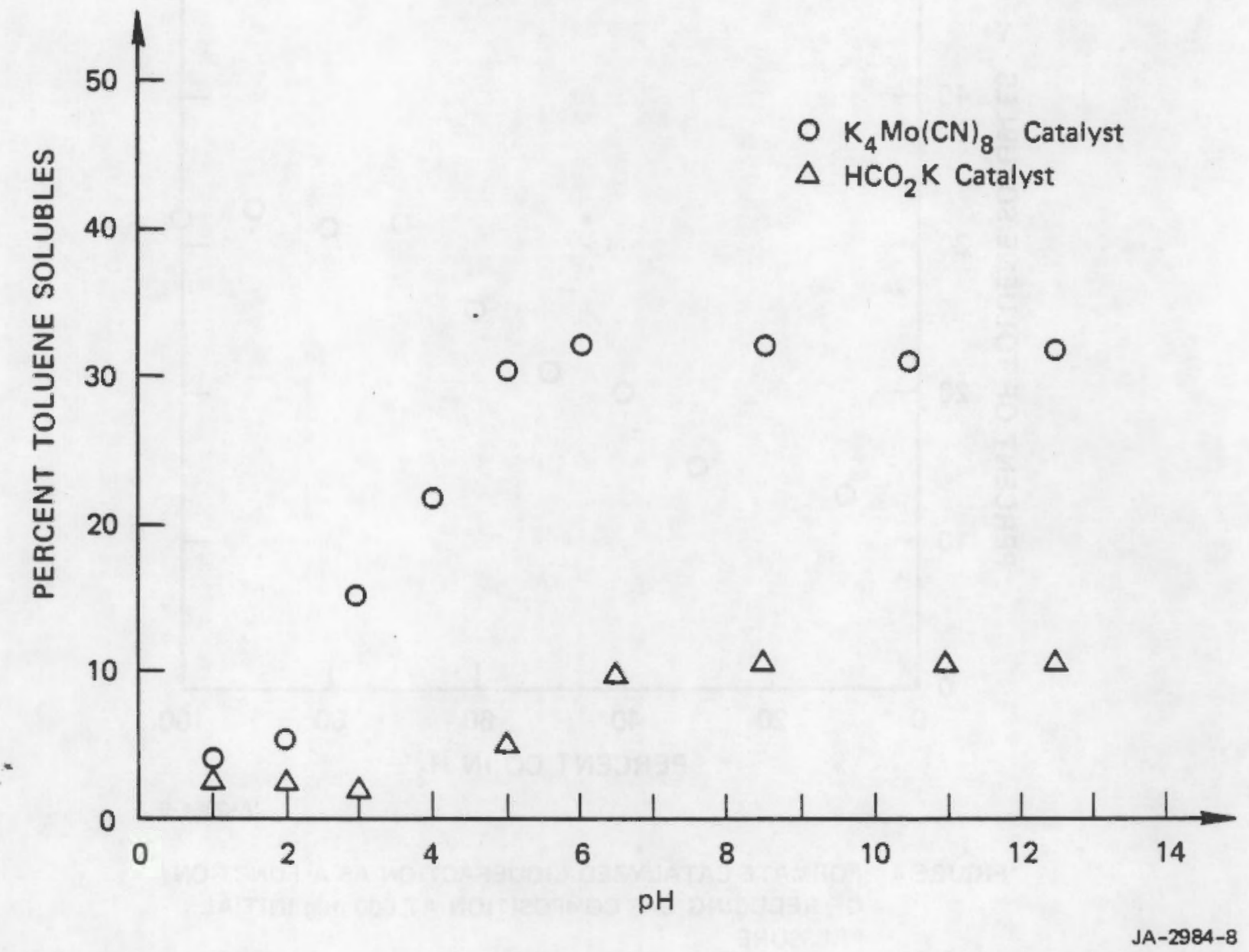

FIGURE 3 PH DEPENDENCE OF WOODMEAL LIQUEFACTION IN A HYDROGEN ATMOSPHERE 


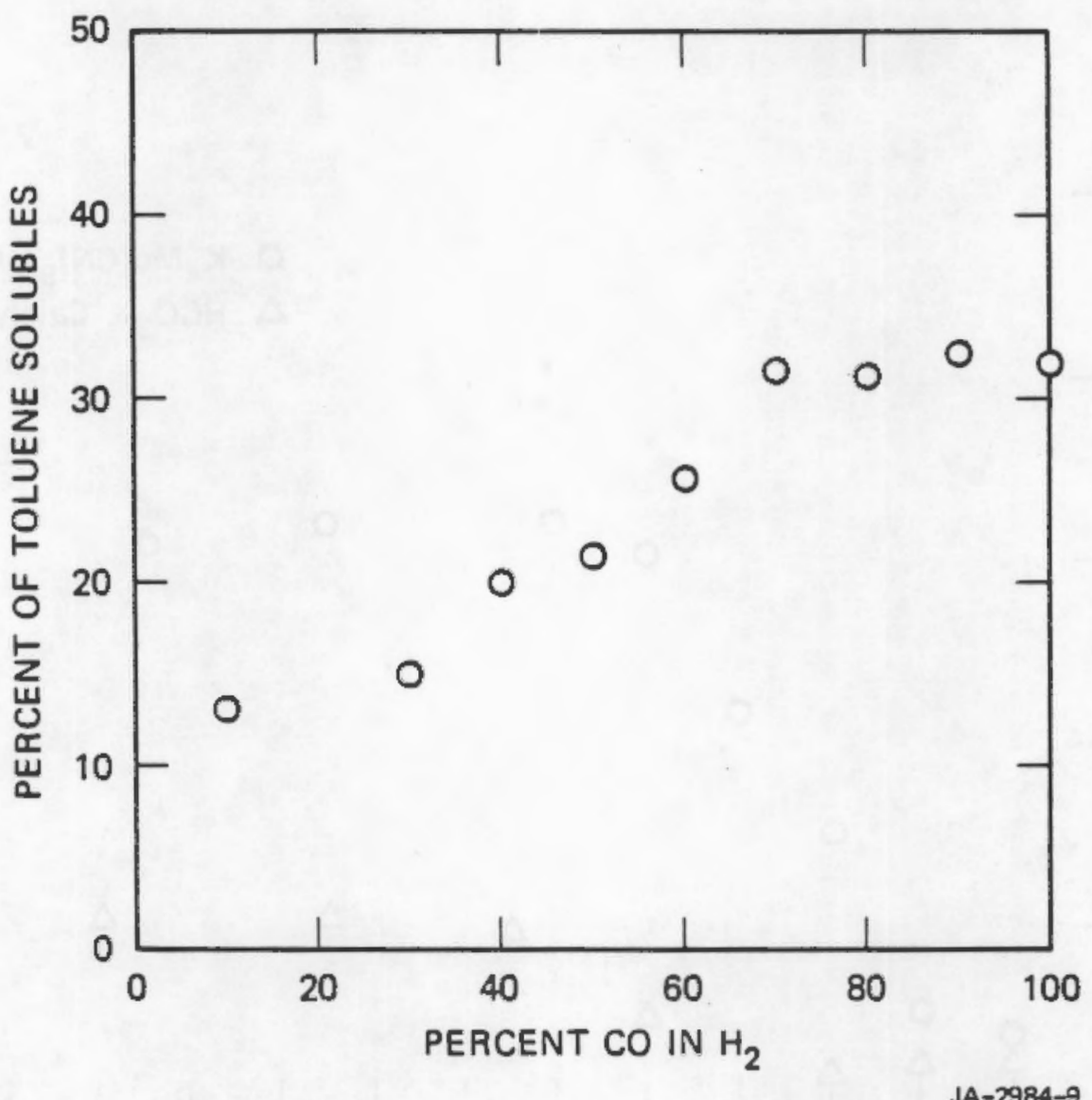

FIGURE 4 FORMATE CATALYZED LIQUEFACTION AS A FUNCTION OF REDUCING GAS COMPOSITION AT 600 psig INITIAL PRESSURE 


\section{FORMATE CATALYZED LIQUEFACTION AS A FUNCTION OF REDUCING GAS COMPOSITION AT 1000 psig INITIAL PRESSURE}

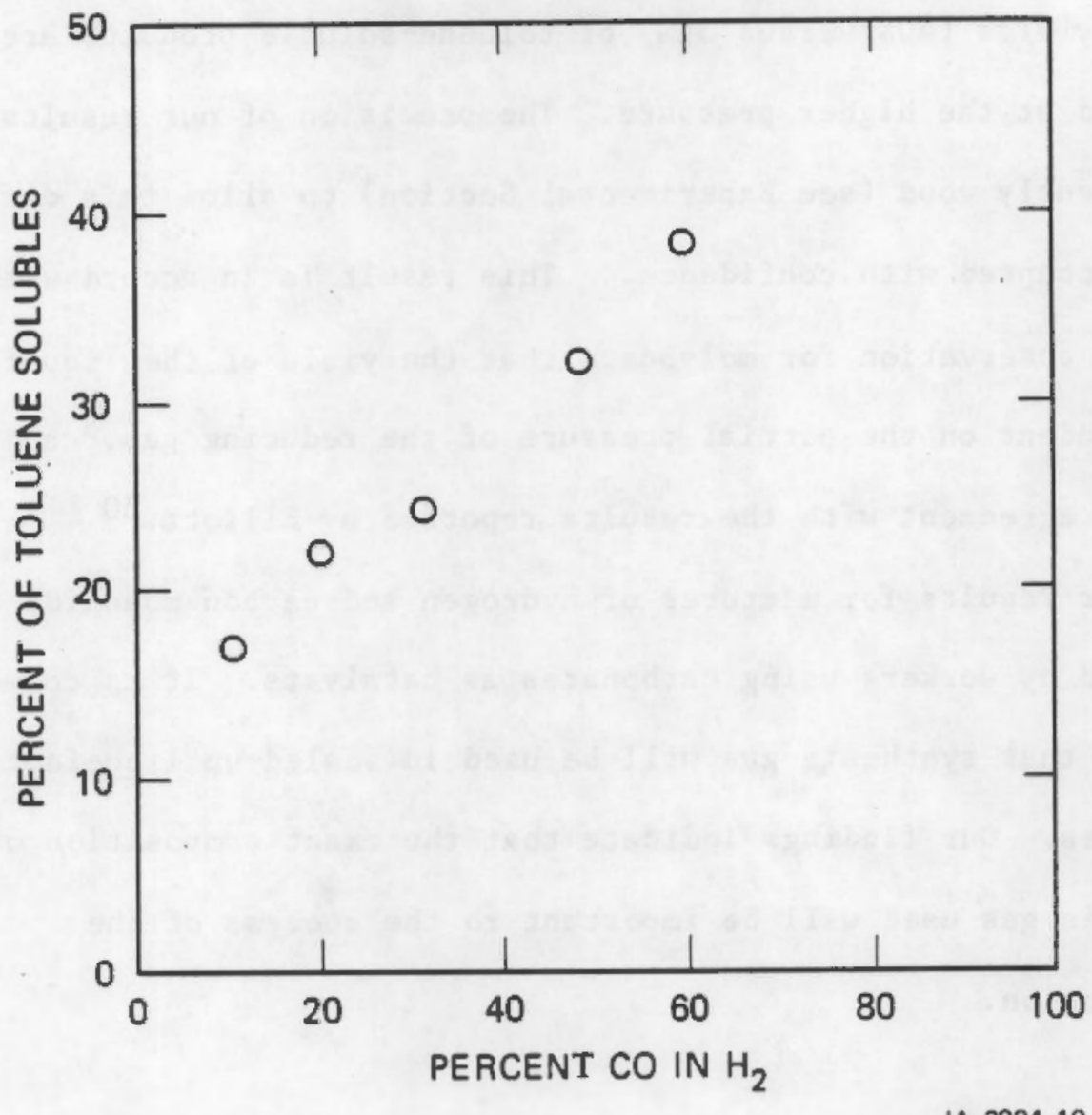

FIGURE 5 FORMATE CATALYZED LIQUEFACTION AS A FUNCTION OF REDUCING GAS COMPOSITION AT 1000 PSIg INITIAL PRESSURE 
shows the results of similar experiments with a starting pressure of 1000 psig reducing gases. When the starting pressure is 1000 psig, full conversion is achieved at $60 \%$ carbon monoxide. Also, considerably higher yields ( $40 \%$ versus $32 \%$ ) of toluene-soluble products are obtained at the higher pressure. The precision of our results is sufficiently good (see Experimental Section) to allow this difference to be accepted with confidence. This result is in accord with our earlier observation for molybdate that the yield of the liquefaction is dependent on the partial pressure of the reducing gas, ${ }^{5}$ and is also in agreement with the results reported by Elliott. 30

Our results for mixtures of hydrogen and carbon monoxide should be noted by workers using carbonates as catalysts. It is commonly assumed that synthesis gas will be used in scaled-up liquefaction processes. Our findings indicate that the exact composition of the synthesis gas used will be important to the success of the liquefaction. 
IV CONCLUSIONS

\begin{abstract}
We have now completed a survey study of the water-soluble salts of all the transition metals that are likely to have utility as catalysts for direct biomass liquefaction in a carbon monoxide steam process. Of the Eifteen metals that we have exanined, certain salts of molybdenum and nickel are the most effective catalysts, and are the only species for which some catalytic activicy independent of the ligand can be shown. The most effective forms of the nickel and molybdenum are cyanide and oxyanion complexes. For nickel the optimum initial oxidation state is +2 ; For molybdenum, +4 . The oxidation state of the proximate metal catalysts under the reaction conditions cannot be determined. The nickel and molybdenum may be forming colloidal suspensions that act as heterogeneous hydrogenation catalysts, or they may be forming proximate catalysts that are truly soluble in the reaction medium.

We have shown that the ligand plays a major role in the liquefaction reaction in carbon monoxide; the role of the ligand is determined by its conversion to formate. The $\mathrm{pH}$ of the slurry is also important in determining the outcome of the liquefaction. While che $\mathrm{pH}$ dependence of the liquefaction correlates to the. pKa of formate, the observation of similar $\mathrm{pH}$ dependencies in hydrogen atmospheres requires caution in drawing such a conclusion.

In a hydrogen atmosphere, formate plays little or no role in decermining the outcome of the liquefaction. It is probable that the metal ion is acting as a hydrogenation catalyst under these
\end{abstract}


conditions. At a starting pressure of 600 psig, a gas composition containing at least $70 \%$ carbon monoxide is required for full formate activity. Because carbonate catalysts presumably act by forning Formate in situ, it is likely that similar results would be observed with carbonate-catalyzed liquefactions. These results bring into question the assumption that hydrogen-rich synthesis gas can be used in a base-catalyzed liquefaction process. 


\section{REFERENCES}

1. H. R. Appel 1, Y. C. Fu, E. G. Illig, F. W. Steffgen, and R. D. Miller, Bureau of Mines, Report of Investigations 8013 (1975).

2. W. L. Berry, Jr. and P. L. Thigpen, "Operation of the Biomass Liquefaction Facility Albany, Oregon," Rust Engineering Co., 13th Biomass The tmochemical Conversion Contractor's Meeting, Washington, DC (October, 1981).

3. H. Davis et al., "Catalytic Liquefaction of Biomass," Lawrence Berkeley Laboratory, 13th Biomass Thermochemical Conversion Contractor's Meeting, Washington, DC (October 1981).

4. F. A. Schooley et al., "Mission Analysis For The Federal Fuels From Biomass Frogram," SRI International, Final Report, Department of Energy, Contract No. EY-76-C-03-115PA-131 (1978).

5. D. 2. Rogers, D. J. Wilhelm, and D. S. Ross, "Feasibility Study on New Processes for Fuel From Biomass," Sumary Report, DOE Contract No, DE-AC03-79ET23023 (1981).

6. S. Ergun, "Review of Biomass Liquefaction Efforts," Final Report, Lawrence Berkeley Laboratory, Department of Energy Contract No. DE-AC03-76SF00098 (1981).

7. o. Routale, Acad. Sci. Fenn. A2(3), 115 (1930).

8. A. Lindblad, Ing. Veternskaps Anad. Hend1, No. 107, 7 (1931).

9. H. Heinemann, Petroleum Refining 33, 161 (1954); H. Heinemann, ibid. 29, $111(1950)$.

10. M. Oshima, K. Kashima, T. Kubo, H. Tabata, and H. Watanabe, Bull. Chem. Soc. Japan 39, 2750 (1966).

11. R. Kashima, Ann. Dept. Noguchi Inst. No. 9, $23(1960)$.

12. K. Kashima, ABIPC 34,817 (1964).

13. A. R. Bowen, J. L. McCarthy, and H. Hibbert, J. Am. Chern. Soc. 65, 1192 (1943).

14. L. M. Cooke, J. L. McCarthy, and H, Hibbert, J. Am. Chem. Soc, $\underline{63}, 2056,3052(1941)$.

15. H. P. Goddard, J. L. McCarthy, and H. Hibbert, J. Am. Chem. Soc. 62, 988 (1940); ibid. 63,3061 (1941). 
16. H. Hibbert, Ann. Rev. Biochem. 11, 18 (1942).

17. Y. Hach ihama and S. Jyodai, J. Chem. Soc. Ind. (Japan) 44, 773 (1941); ibid. 45,302 (1942); ibid. 46, 132, 304 (1943); ibid. 47,763 , $781(1944)$.

18. Y. Hachihama et al., J. Chem. Soc. Ind. (Japan) 47, 218 (1944).

19. Y. Hachihama, S. Jyodai, and M. Takeda, J. Chem. Soc. Ind. (Japan) 47, 215 (1944).

20. A. R. Bowen, H. G. Shatwel I, and A. W. Nash, J. Chem. Soc. Ind. 45, 507 (1947).

21. J. M. Pepper and H. Hibbert, J. Am. Chem. Soc, 70, 67 (1948),

22. K. Snajberk and E. Savarin, Tappi 53, 1507 (1970).

23. Y. Hachihama, S. Jyodai, and M. Umezu, J. Chem. Soc. Ind. (Japan) 43, 144 (1943).

24. P. F. Ritchie and C. B. Purves, Pulp \& Paper Mag. Can. 48, 12, 74 (1947).

25. D. G. B. Boocock, D. Mackay, M. McPherson, S. Nadeau, and R. Thurier, Can. J. Chem. Eng. 57, 98 (1979).

26. A. Sakakibasa, ABIPC 34, 1868 (1964).

27. A. Sakakibasa, I, Abe, and T. Craki, ABIPC 33, 360 (1963).

28. A. Sakakibasa et al., Makugai Gakkaishi 15, 84 (1969); CA 71 , 82805 u (1971).

29. A. Sakakibasa and T. Araki, Hood Res. Soc. 7, 19 (1961).

30. D. Elliott, Battelle Pacific Northwest Laboratory, personal communication, (1982). 
PNL -5617

UC-610

DISTR IBUTION

No. of

Copies

OFFSITE

Simon Friedrich

Biomass Energy Technology

Division

Forrestal Building (CE-321)

J.S. Department of Energy

1000 Independence Avenue

Washington, DC 20585

30 DOE Technical Information

Center

\section{DNSITE}

DOE Richland Operations

D. R. Segna

10 Pacific Northwest Laboratory

G. F. Schiefelbein

D. J. Stevens

M. A. Gerber

Publishing Coordination (2)

Technical Infomation (5) 


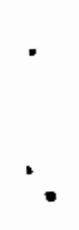

